\title{
Cruising along the river Danube - Contemporary tourism trend in Serbia
}

\author{
Aleksandra S. Dragin A* Dobrica JovičićB ${ }^{\mathrm{B}}$, Tamara LukićA \\ Received: October 2009 | First Revised: December 2009 | Second Revised: July 2010 | Accepted: July 2010
}

\begin{abstract}
The subject of this paper are international cruises along the Pan-European Corridor VII [Danube Waterway]. We tried to identify the structural properties of cruises along the Corridor VII, determine the scope and dynamics of cruises along the Corridor VII, define the problems and point to perspectives of cruises along the Corridor VII in Serbia.

The research presented in this paper suggests that adequate valorization of the Danube along its entire navigable stream is a 'quick win' option for Serbia's tourism. The related research, also, suggests positive effects that the cruises have upon the economic and socio-cultural development of Serbia. In order for cruises along the Corridor VII to provide prosperity in the forthcoming period, it is necessary that this form of tourism be integrated into plans of tourism development of the entire Corridor VII and Serbia as a whole. Without adequate plans, the reconstruction of the existing and new infrastructure and increase in service quality, it is reasonable to expect a decline in the competitiveness of the Serbia's supply at the cruise market.

The basic methods used while obtaining and processing data and analyzing the results are: field research, historical method, statistical procession, quantitative and qualitative content analyses, comparative method [Benchmark analysis etc.]. A particular significance was given to the PESTEL analysis.
\end{abstract}

Key words: nautical tourism, cruises, Corridor VII, Danube, Serbia, demography, transition.

\section{Introduction}

Cruises are constantly increasing in popularity worldwide, as they present an attractive form of modern tourist traffic (CLIA, 2005; Marti, 2004; Ward, 2005; Peisley, 1992, 2006; Hobson, 1993; Gibson, 2004, 2008). Over the last decade, cruises have become a tourist niche with the fastest growth rate. Compared to international travel the demand for which has increased by $4.3 \%$, cruising alone has recorded the growth of $7.9 \%$ (WTO, 2003; Dowling, 2006).

In the year 1995 about 5.7 million tourists were on cruise, and in 2006 the number increased to I6 million tourists. It is expected that the number of tourists on cruise will rise to 20 million in 2012 (Dowling, 2006). The major cruising destinations include Northern and Central America (57.15\%), followed by Europe (24.10\%). The international nautical market of still waters (rivers and canals) has been focused on Europe, Africa (the Nile River) and the Far East (the Yangtze River) (Dowling, 2006).

Trends on the market of river cruises are conditioned by the following factors: the high living standard of the population in key emittive areas (Northern, Western, and Central Europe and the USA), the increasing competition between companies that are lowering the prices of their tours (for example, cruisers from Russia, Ukraine and Bulgaria), the appearance of new segments of tourist demand and supply, the need for safer traveling, etc. Tourism based on river cruising records a remarkable growth. The greatest rise is expected to occur in new European destinations (Hungary,

A University of Novi Sad, Faculty of Science, Department for Geography, Tourism and Hotel Management; Trg Dositeja Obradovica 3; 21000 Novi Sad; Serbia

B University of Belgrade, Faculty of Geography; Studentski trg 3/II; 11000 Belgrade; Serbia

* Corresponding author: Dragin Aleksandra: e-mail: saskageo5@yahoo.com ;

Co-authors: Jovičić D. dobricaj@eunet.rs ; Lukić T. snstamara@yahoo.com 
Romania, Slovakia, Serbia), primarily due to the Danube as an object of demand in cruising tourism (Sofield, 2006). This has been confirmed by the data that in 2003 almost 393 thousand tourists cruised along the Danube (The Government of the Republic of Serbia, 2006).

The cruises along the Corridor VII are characterized by complexity, i.e. multiplicity, which is the result of the fact that they are the object of interest and demand of tourists from a great number of countries in Central and Southeast Europe (Dragin, Dragin, Plavša, Ivkov, Djurdjev, 2007). Each one of them presupposes specific conditions of the offer and organization as well as specific strategy of the cruise-tourism development (Dwyer, Forsyth, I998; Dragin, et al, 2008).

Previously published works on cruise tourism mainly deal with the problems from the fields of economy and sociology, i.e. anthropology. The economic impact and benefits of the cruising tourism has been researched by a number of authors (Dwyer, Forsyth 1996; Hall, Braithwaite, I990; Hobson, I993; Mescon, Vosikis, I985; Foster, I986; Braun, Xander, White, 2002; Brida, Aguire, 2008; Chase, Alon, 2002; Henthorne, 2000; Dragin, et al, 2006; Dragin, 2010). However, it still represents an insufficient research area.

More recent research has paid more attention to identifying different factors influencing cruise decision making such as loyalty (Li, Petrick, 2008; Petrick, Sirakaya, 2004; Petric, 2004), price sensitivity (Petrick, 2005), and the service quality, value, and satisfaction of cruisers (Duman, Mattila, 2005; Petrick, 2004; Field, Clark, Koth, I985; Gabe, Lynch, McConnon, 2006; Guyer, Pollard, I997; Jaakson, 2004; Marti, I992, Teye, Leclerc, I998; Petrick, 2003; Qu, Wong, Ping, I999; Armenski, Pejovic, Dragin, 2009; Armenski, Zakić, Dragin, 2009).

Almost all studies that concern sociological, anthropological and even ethical matters of cruise personnel (Wood, 2000), refer to trans-ocean cruises organized by Princess Cruises, Norwegian Cruise Line, $\mathrm{P} \& \mathrm{O}$ Cruises and Royal Caribbean Cruises, who dominate the Cruise Industry (Mancini, 2000). Onboard hotel operations are comparable to a standard resort operation (Teye, Leclerc, I998) performing customer service functions such as customer care, scheduling activities, meals, etc.

It is rather difficult to find a research that covers the cruises along European receptive areas, especially on rivers which are becoming more and more popular way of spending free time. Moreover, almost all the published studies that deal with cruising treat tourists as their main object of interest (e.g.. Dowling, 2006; Li, 2006; Petrick, 2003; Petrick, 2004; Hung, Petrick, 20I0; Petrick, Sirakaya, 2004; Armenski, Zakić, Dragin, 2009; Dragin, Đurđev, Armenski, 2008).
The affirmation of this topic was encouraged by numerous facts that refer to unquestionably multi-effective impact that international cruises have upon receptive countries. This means that cruise tourism can function as a strong impetus for reviving those regions that during the past two decades have been in transitions (social, political and economic).

If we take facts and present situation into account, based on the field research of the Corridor VIl cruises and from the perspective of tourist flow, we believe that the analyses introduced in this study are the basis for further material investment in the development characteristic of this matter.

\section{Sampling and methodology}

The region under analysis comprises the Corridor VII (waterways of the Danube: Regensburg - the Black Sea). More specifically, the research includes $93.7 \%$ of the Corridor, that is $2.227 \mathrm{~km}$ of the Danube stream (from Passau to the Danube Delta), as this is the section cruised by tourist ships. Key countries in the region include Austria, Slovakia, Hungary, Croatia, Serbia, Romania and Bulgaria, as well as the border regions of Germany, Moldavia and Ukraine. It should be stressed that five European capitals are located on the Corridor VII - Vienna, Bratislava, Budapest, Belgrade and Bucharest - which makes this region highly attractive to tourists.

The selection of the region for analysis was affected by current cruising trends, thus suggests that the Corridor VIl is a waterway characterized by an impressive tourist interest of global extent. Due to this, Serbia has been a significant tourist destination since 2002, as well as other countries in the itinerary.

The central region of investigation comprises the part of the Danube flowing through Serbia, that is the section from Bezdan (the border between Serbia and Croatia) to the confluence of the Timok and Danube (the border triangle between Serbia, Romania and Bulgaria).

The motivational and spatial base of herein analyzed cruises is the Serbian section of the Danube $(588 \mathrm{~km})$ and those natural and social values in the Danube banks region attracting tourists. Every $4^{\text {th }}$ inhabitant of Serbia live in the observed area ( $55.5 \%$ of the Serbian territory), which points to the significant concentration of Serbian population in the Danube region. The population density in the region is 145.8 inhabitants per $\mathrm{km}^{2}$, which is significantly above the average density in Serbia as a whole (84.9 inhabitants per $\mathrm{km}^{2}$ ) (The Statistical Office of the Republic of Serbia, 2006). 
The basic methods used while obtaining and processing data and analyzing the results are: field research, historical method (written documents, statistical data, research of the results from similar researches etc.), statistical procession of literature and other material, quantitative and qualitative content analyses, comparative method.

The data for this study (the statistical an comparative method) has been collected from the manifests of all cruises which docked in Serbia (Novi Sad and Belgrade) in period 2002-2009 ${ }^{\mathrm{I}}$. The data were obtained from the Novi Sad Port, Beograd Port, the Border Police Station of Novi Sad, the public company 'Gradsko Zelenilo - Novi Sad', the Border Police Station of Donji Milanovac, the ships on cruise along the Corridor VIl, as well as from travel agencies in Serbia ('Jugoagent', 'PBA', 'Brodokomerc'). The selection of the year 2002 as the initial one was conditioned by the fact that in this year the Serbian section of the Danube was included in modern cruises along the Corridor VII. Based on this, the characteristics of tourist traffic were identified (the number of tourists, visits by season, etc.).

A particular significance was given to the PESTEL analysis as an objective indicator of tourism development in a given area, i.e. the Serbian section of the Corridor VIl. Using this analysis, we defined and treated individual and joint influences of the political, economic and social factors, at the given technical and technological level of development in Serbia, under given ecological conditions, and within the relevant legal framework. The very name of the analysis is an acronym made up from the initial letters of the above mentioned factors: political (P), economic (E), social (S), technological (T), environmental (E) and legal (L).

We also used the Benchmark analysis for the comparison of numerous parameters and properties of international cruises along the Corridor VII.

Analysis of the contribution of the Corridor VIl cruises to tourism: This was done by means of written data sources analysis, surveys, interviews with tour-operators, captains and crews on ships, agencies, and forwarding agents. The anal-

1 After the bridges on the Danube in Novi Sad were bombed in I999, the clearance of the Danube basin in that area was commenced by the support of the European Union, the Danube Commission and Corridor VII-Management/ TINA Vienna. Two new bridges were built and one pontoon bridge was constructed, with the opening schedule of three times a week to make passage for ships. Thus, the Danube was at least, even with some restrictions, made navigable again as far as to its delta in Romania. On the initiative of the Danube Tourist Commission, passenger ships did not have to pay any toll. So, the first observed year was 2002, as a year when cruises along the Corridor VIl began on the Serbian section of the Danube. yses were done at following locations: the ports 'Novi Sad II', 'Novi Sad', and 'Beograd', the Border Police Station of Donji Milanovac and ships 'River Aria', 'Heinrich Heine', 'Ms Johann Strauß, 'Maxima', 'Ms Victor Hugo', 'River Adagio', 'Beethoven', etc. Analysis of the contribution of the Corridor VII cruises to Serbian tourism: This was done by means of surveys and interviews with representatives of travel agencies ('Putnik'), transportation companies ('Vojvodina' and 'Putnik'), restaurants (MB 'Rodic'), museums (the Museum of the City of Novi Sad, the Ethnographic Museum in Belgrade), etc.

\section{Results}

\section{Tourism products created trough cruises along the Corridor VII}

Cruise tourism represents a form of tourist traveling along a given hydrographic object and sojourn on a ship specialized for this type of traveling. The tourism product created during this traveling type is not easy to define due to its complexity, heterogeneity and spatial and temporal segmentation. A key factor for its overall existence and market affirmation lies in the presence of tourists-consumers.

In addition to material components, other non-material components-services also take part in the creation of the tourism product (Duman \& Mattila, 2005; Gibson, 2006). The value of the product represents a combination of quality, needs, expectations, and price. It is therefore necessary that supply creators (cruise-companies) be able to make predictions about potential tourists' needs and to satisfy them, through available material, spatial, technical, organizational and human resources. In addition, the price should be adjusted to the payment ability of potential customers (Petrick, 2005, Williams \& Hall, 2000). It follows then that the tourism product is a total product which comprises three elements: the core of the product (cruising), the formal product (the physical product, i.e. ship, food, bed, seat on a ship) and the extended product (excursions, recreational activities, cultural programme, entertainment) (Go \& Pine, I995).

The standardization and specialization in cruising services can lead to the balancing of quality at the level of the core product and to some extent at the level of the formal product. Creating a recognizable product brand is based on the extended value of the product. Specifically, in the extended value of the product lies the essence of the extra value for the guest. Consequently, cruisecompanies do not only want to synchronize the expected and experienced benefits of their cus- 
tomers, but they also tend to overcome the expected by increasing the scope of the benefits for tourists.

The cruising season along the Corridor VII comprises the period March through November. Tour-operators offer various trips along this destination which can last from Io days to four weeks (Dragin, Bubalo-Živkovic, Ivanović, 2009).

The ship as the basic material element of cruises along the Corridor VII faces the problem of limited space for production and offering services to tourists. At the same time, tourists should not get the impression that the space is cramped or is lacking during a cruise.

The American company 'Grand Circle Travel' (Boston, USA) is one of the leading river cruise companies in the world. With respect to the cruises along the Corridor VII, it has launched a tour named 'Eastern Europe to the Black Sea' by using ships 'River Adagio' and 'River Aria' (Grand Circle Travel, 2005). The cultural treasures and natural values of the bank region of the Danube make the significant quality component of this supply. The tour includes a cruise along the Corridor VII through five countries (Hungary, Croatia, Serbia, Bulgaria and Romania) and lasts 13 days with a possibility of four additional nights in Prague and/or four nights in Transylvania (Romania) and Bucharest (Grand Circle Travel, 2005).

According to the creators of this tour, its main attributes include: the acquaintance with the cultural and historic treasures of five former socialist countries; a visit to the Memorial Center of Josip Broz Tito (the man who is believed 'to have liberated the former Yugoslavia from communism'); a passage through the Iron Gate (the most attractive part of the supply) where the Danube cuts across the Transylvanian Alps; experiencing traditional Croatian hospitality with a presentation of ethnic specificities of the local communities and consumption of domestic food; and a view upon a lively scenery of Romania during the rail travel on the route Constanta-Bucharest.

Three days are spent on a cruise through Serbia. In Novi Sad (Day 7), tourists visit the old town and attend cultural and entertainment events (a cultural group performs traditional Serbian folk dances on the ship). The visit to Belgrade (Day 8) includes a tour of the old city, the Kalemegdan Fortress, the City Parliament, the St. Sava Orthodox Church (one of the biggest in Europe) and the Memorial Center of Tito. During the third cruising day through Serbia (Day 9), tourists visit the Djerdap Gauge, the medieval city Golubac and the Transylvanian Alps. Particularly interesting is the passage through the Iron Gates.

The 'Vantage Delux World Travel' company (Boston, USA) offers three tours that include Ser- bia as part of the Corridor VIl cruises (Vantage, 2007). This tour includes numerous ethnic, social and cultural programmes with the possibility of visits to various sites offshore.

The French company 'Croisi Europe' launched two cruises along the Corridor VII, the itinerary of which includes destinations in Serbia as well (available at http://cruise.croisieurope.com - accessed on 25 October 2008).

According to the Danube Tourism Commission, 'Peter Deilmann' is the leading cruise company in Germany founded in I983. This company offers two tours on the route Passau - Tulcha (available at http://www.danube-river.org/site/ content - accessed on I5 June 2007). The specificity of both tours is that, unlike other tours with Serbia as an itinerary destination, they include not only a sightseeing tour of Belgrade but also the possibility of visiting historical sites (Topola and Arandjelovac).

The German company 'Phoenix Reisen Gmbh' has the greatest number of tours along the Corridor VIl, part of itinerary of which is Serbia (Phoenix Reisen Gmbh, 2006).

The specificity of cruises offered by the 'Phoenix Reisen Gmbh' company lies in the fact that Ukraine is included in, while Croatia is excluded from many of the itineraries (the ship passes through Croatia but does not stop on the land). With respect to Serbia, the specificity of the supply lies in the possibility of visiting the monastery of Krusedol, in addition to standard visits to Belgrade and Novi Sad.

Other cruise companies tend to present Serbia to their clients through programmes two-three days long, which suggests that the recognizability of the tourist attractiveness of Serbia is considerable and much balanced along cruise companies.

\section{Scope and dynamics of tourist traffic}

The tourist traffic is quantitative and qualitative indicator of the supply attractiveness, that is, the recognizability of a particular tourist destination on the market. Tourist traffic is also the result of good promotional appearance of the supplier. However, it is often impossible in tourism to precisely determine the tourist traffic, that is, to specify the number of people who have visited a specific country. This is due to the fact that during their stay in a given country some tourists may stay in more than one place. In such situations, they would pay a sojourn tax upon each change of place and consequently be registered several times.

The same applies to tourists on cruises along the Danube, as well as to ships. For example, during many tours in Serbia, ships land in both Novi Sad and Belgrade and, also, in Donji Milanovac 
Table 1 Total annual number of tourists on the Corridor VII in Serbia

\begin{tabular}{|l|r|r|r|r|}
\hline Year & \multicolumn{1}{|c|}{ Belgrade } & \multicolumn{1}{c|}{ Novi Sad } & The Iron Gate [Kostolac / Donji Milanovac] & \multicolumn{1}{l|}{ Total in Serbia } \\
\hline 2002. & 4,316 & 7,869 & - & 12,185 \\
\hline 2003. & 17,441 & 13,029 & - & 30,470 \\
\hline 2004. & 36,580 & 26,445 & - & 63,025 \\
\hline 2005. & 46,895 & 49,278 & - & 96,173 \\
\hline 2006. & 44,952 & 40,635 & - & 85,587 \\
\hline 2007. & 50,857 & 66,221 & - & 117,078 \\
\hline 2008. & 52,027 & 56,380 & 45 & 108,452 \\
\hline 2009. & 49,670 & 58,096 & 89 & 107,855 \\
\hline Total & 302,738 & 317,953 & 134 & 620,825 \\
\hline
\end{tabular}

Source: Dragin, 2008; Pier „Novi Sad“; Pier „Belgrade”, the Border Police Station of Donji Milanovac

(or Kostolac). During some other tours, ship landing in only one of the two cities is planned, with an option to visit the other. Each landing is registered as a new statistical datum, so in case a single ship lands in two ports during the same tour, this is statistically recorded as two ships. The same applies to tourists - passengers on cruisers. It is for this reason that a valid representation of the number of tourists on a cruise along the Corridor VII in the period 2002-2009 is taken to be the sum of the quantity registered in both Novi Sad and Belgrade (Table I).

It can be noted that the number of tourists on the Corridor VII is increasing every year, with the exception of 2006. The reasons can be found in the extremely high water level of the Danube in April and May 2006, due to which many cruises were cancelled (Dragin, 2008).

The growth of the significance of cruise tourism is best explained by looking at the data about the participation of tourists on cruises along the Corridor VIl in the overall inbound tourism in Serbia. In 2002, cruise tourism participated with $3.9 \%$ of all inbound tourism in Serbia, in 2004 with $\mathrm{I} 6 . \mathrm{I} \%$ and in 2005 with the so far highest proportion of 21.2\%. In 2006, cruise tourism in Serbia fell to $14.6 \%$ only (the effect of the high water level of the Danube), and rise to $16.7 \%$ in 2009 (The Sta-

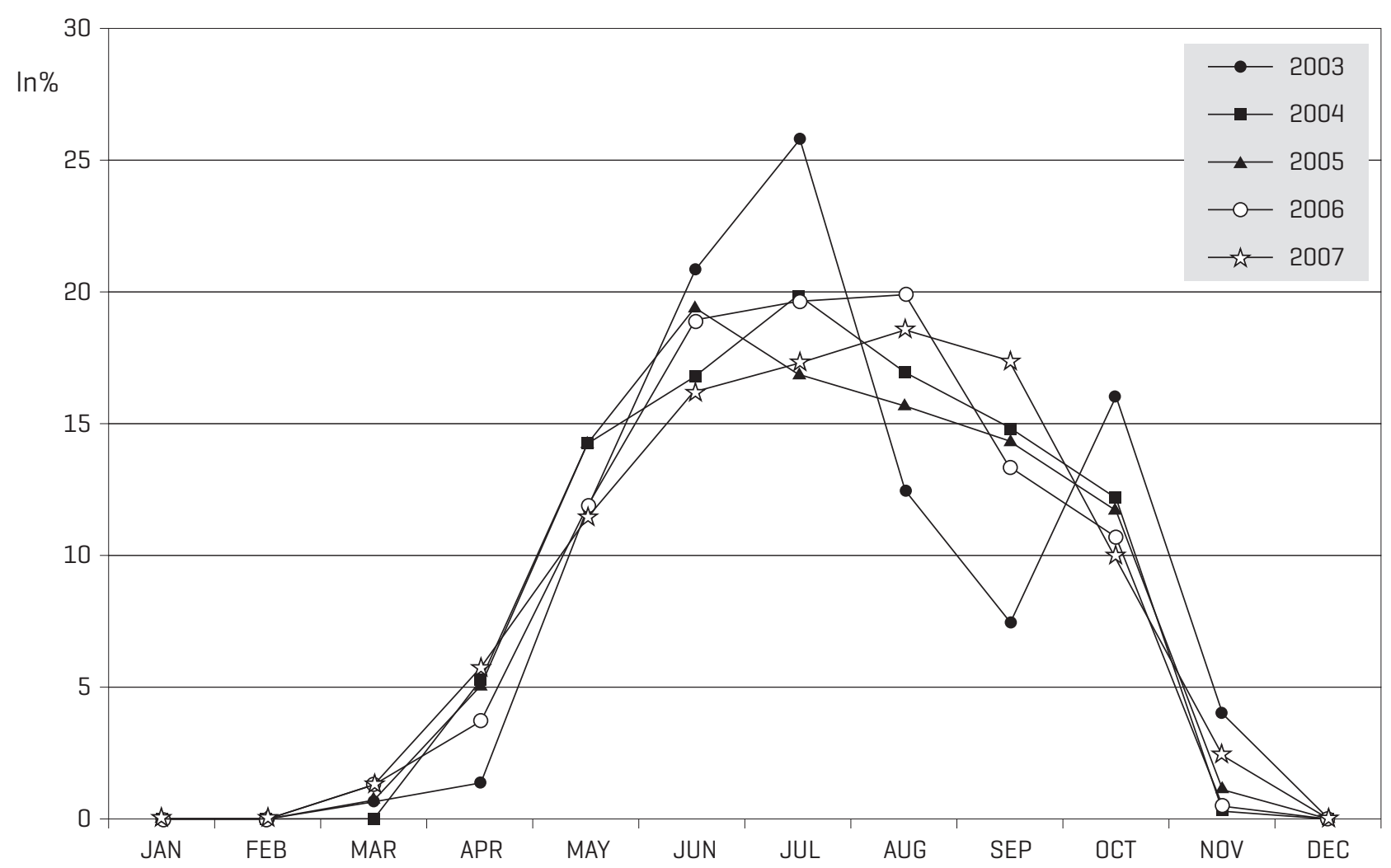

Figure 1 Monthly tourist traffic along the Corridor VII in Serbia [\%] Source: Dragin, 2008. 
tistical Office of Serbia (2006, 2008); Data of the 'Novi Sad' Port and 'Beograd' Port; http://www.srbija.travel/turisticki-promet-u-republici-srbiji-u2009-godini/).

The analysis of the monthly tourist traffic on the Corridor VII in the period 2002-2007, shows tendency that the maximum visits were made in the summer. The exception is the year 2003 when there was a rapid fall in the tourist traffic in August and September, which was in contrast with the global trend in 2003, when a sharp fall was recorded in the first four months of the same year (conflicts in Irak). However, due to the unexpected SARS breakout in April and May 2003, there was an overflow of the international demand from Asia and Pacific to Europe and other regions. This probably affected the Corridor VIl, where in June and July 2003 good results were achieved.

\section{PESTEL analysis}

PESTEL analysis is commonly used as an objective indicator for the justification of tourism development (in this particular case, the launch of cruises along the Corridor VIl in Serbia). This analysis defines and treats individual and joint effects of the political, economic, and social factors at a given technical and technological level in actual environmental conditions and within the current legislature. The factors are analyzed as advantages/disadvantages, that is, positive/negative sides/ limitations for tourism (Table 2).

For the purpose of a better positioning at the international market, Serbia must employ the model of development which will provide for competitive advantages of cruises along the Corridor VII in Serbia, compared to similar destinations in Europe. This model must take into account the satisfaction of tourists and tourism services providers, environmental protection, promotion of local culture and traditional values. The key prerequisite for its implementation is the stability of the political situation in Serbia and its surroundings (Jovicic, 2000).

All countries of the Pan-European Corridor VII, did not have sufficiently developed river nautical tourism until the popularization of cruises. Serbia had plenty of positive effects thanks to the tourist flow, especially regarding foreign tourism. These effects were really needed after the I990's and all the problems this country and its people went through.

Firstly, it was a part of a country which changed borders and names on several occasions during the last decade of the $20^{\text {th }}$ century. From former Yugoslavia it was reduced to the territory of the Republic of Serbia. These changes were followed by numerous wars, terrible foreign politics, sanctions (both political and economic ones), an over- all country crisis (economic, financial and social). The country which used to have a positive tourist image, now disappeared from the pages of tourist brochures. What is more, the Adriatic coastline, which represented the basis of former Yugoslav tourism, was no longer within reach of the Serbian territory.

With the democratic changes in I999, Serbia started its transitional processes, trying to shape its tourist offer as well. Eventually, by creating documents which are concerned with the conception of tourism strategy of the Republic of Serbia (MHCEF, 2005; MHCEF, 2006a; MHCEF, 2006b), it distinguished nine key products, cruises being one of them, representing the path of further tourist integration of Serbia.

Also, according to 'the Strategy for Tourism of the Republic of Serbia up to 20I5' (The Government of Republic of Serbia, 2005), the product of nautical tourism in Serbia will be based on the strategic potentials of the Danube as the leading river cruise destination in Europe. According to this document, the positioning of Serbia should evolve around three systems of values: valorization of the concept of the Balkan; valorization of the Danube and integral interpretation of the set of Serbian values.

Among the expert public, the dominant opinion is that the second option - the Danube - could provide the best short-term effects. The valorization of the Danube along its entire navigable stream is a 'quick win' option for Serbia. None of the countries in the Danube region uses this concept in their promotive slogan, even though the Danube is a remarkable tourism resource of the global importance. The size and importance of the Danube in Serbia may be an impetus for tourism development in Serbia as a whole.

Although there is no consensus among experts on the importance of the hierarchy of the above mentioned systems for the tourism positioning, it should be noted that all three options take part in the positioning of Serbia at the market of the Corridor VIl cruising tours.

The Danube, the spine of the Corridor VIl, is the northern border of the Balkans. Due to the wealth of tourist attractions, the Balkans can be the dominant motivational force in cruising tours along the Corridor VII. On the other hand, the set of Serbian values that requires an integral interpretation includes: Serbian culture, people, art, hospitality, passion and pride, a combination of the traditional and the modern, etc. This value set can be verified on the market through the following contents: short breaks in Belgrade, tours through Serbia, river cruises through Serbia, cultural events, experiences in the rural areas and spa resorts. 
Table 2 PESTEL analysis of cruises along the Corridor VII in Serbia

\begin{tabular}{|c|c|}
\hline ADVANTAGES & DISADVANTAGES \\
\hline \multicolumn{2}{|c|}{ Political Factors } \\
\hline $\begin{array}{l}\text { Peace in the region. } \\
\text { Serbia is undertaking the processes of EU integration through } \\
\text { the Stability Pact for Southeastern Europe. } \\
\text { All the political parties have reached the agreement on the } \\
\text { need for economic development. } \\
\text { There is awareness among the leading political parties of the } \\
\text { importance of tourism development on the Danube. } \\
\text { The National Tourism Organisation has been established. }\end{array}$ & $\begin{array}{l}\text { Insufficient cooperation between the public and the private } \\
\text { sector in the region. } \\
\text { - Significant centralization of the political power at the state } \\
\text { level. } \\
\text { - Lack of strategic planning aimed at strengthening the market } \\
\text { competitiveness of nautical tourism on the Danube. } \\
\text { - Frequent changes of political power affect the strategy of } \\
\text { tourism development. } \\
\text { - It is still more important who the initiator is [political party] } \\
\text { than what the idea is. }\end{array}$ \\
\hline \multicolumn{2}{|c|}{ Economic Factors } \\
\hline $\begin{array}{l}\text { The Serbian economy has shown some stability and } \\
\text { growth [stable currency, GDP rise, growth of international } \\
\text { investments]. } \\
\text { Favourable geographic position that can be verified } \\
\text { economically - the Danube region, the Middle European region, } \\
\text { the border region. } \\
\text { Developed agriculture [complementary with tourism]. } \\
\text { Qualified and specialized human resources understanding } \\
\text { current market trends. } \\
\text { Human resources, although insufficiently engaged, are willing } \\
\text { to adapt to tourism needs on the Corridor VII in order to foster } \\
\text { economic development. }\end{array}$ & $\begin{array}{l}\text {. Insufficiently stimulating business environment. } \\
\text { - Economic inefficacy of the economic subjects. } \\
\text { - A high rate of unemployment in the Serbian Danube region. } \\
\text { life. } \\
\text { - Lack of strong companies that are highly competitive at the } \\
\text { market. } \\
\text {. The growth of investment after all does not proceed with the } \\
\text { expected dynamics. } \\
\text {. Promotion of nautical tourism is at the bud. }\end{array}$ \\
\hline \multicolumn{2}{|c|}{ Social Factors } \\
\hline $\begin{array}{l}\text { Tradition. } \\
\text { Hospitality. } \\
\text { Young and educated stuff. } \\
\text { Visits by German and Serbian tourists who originate from the } \\
\text { Serbian Danube territory [they live abroad, but their ancestors } \\
\text { originate from this territory]. }\end{array}$ & $\begin{array}{l}\text { - Negative demographic trends [aged population, the negative } \\
\text { rate of population increase; migration of the young population } \\
\text { ]. } \\
\text {. The importance of tourism has not yet been acknowledged by } \\
\text { all social structures [e.g. elderly population]. } \\
\text {. Inertia, lack of initiative, passivity of the domicile population. }\end{array}$ \\
\hline \multicolumn{2}{|c|}{ Technical-technological Factors } \\
\hline $\begin{array}{l}\text { Serbia has started technical and technological modernization } \\
\text { in order to join the processes of EU integration. } \\
\text { Developed transport infrastructure in places where ships land. } \\
\text { Ports in Belgrade and Novi Sad have been better equipped. }\end{array}$ & $\begin{array}{l}\text { Necessary revitalization of the regional and local road } \\
\text { infrastructure along the Corridor VII according to the } \\
\text { international standards. } \\
\text {. Information about traffic and tourism are scarce, the traffic } \\
\text { signalization system is incomplete and unevenly spread. }\end{array}$ \\
\hline \multicolumn{2}{|c|}{$\begin{array}{l}\text { Environmental Protection } \\
\end{array}$} \\
\hline $\begin{array}{l}\text { Relatively preserved nature. } \\
\text { Adequate safeguards against floods. } \\
\text { Increased awareness of the population about the need for } \\
\text { environmental protection. } \\
\text { Activities of NGOs in Serbia. } \\
\text { Positive urban measures for environmental protection [waste } \\
\text { pits]. } \\
\text { Cruise companies have a high level of awareness about the } \\
\text { need for waterways protection. }\end{array}$ & $\begin{array}{l}\text {. There is no methodology for monitoring the environment along } \\
\text { the Corridor VII in Serbia. } \\
\text {. There is no programme for protection of waterways and inland } \\
\text { against air pollution [green belts as tampon zones]. } \\
\text {. Uncontrolled waste pits and unregulated disposal of waste } \\
\text { into waterways of the Corridor VII. } \\
\text {. Intensive usage of chemical products in agriculture. } \\
\text { - Insufficient number of programmes for reduction of } \\
\text { environment pollution. } \\
\text { - There is no legal sanctioning of the subjects who negatively } \\
\text { affect the environment along the Corridor VII in Serbia. }\end{array}$ \\
\hline \multicolumn{2}{|r|}{ Legal Aspects } \\
\hline $\begin{array}{l}\text { Serbia has started the process of adjustment of its legislature } \\
\text { in accordance with the EU standards. } \\
\text { Less complex procedure for work licenses and building up } \\
\text { tourist facilities. } \\
\text { Less complex procedure for starting a business. } \\
\text { Stuff can be hired part-time or seasonally. } \\
\text { The law on local autonomy has been adopted, which is a step } \\
\text { further away from the old legislature. }\end{array}$ & $\begin{array}{l}\text { Inconsistent application of law and other regulations. } \\
\text { - Centralization of power [insufficient integration of local } \\
\text { authorities in international agreements]. }\end{array}$ \\
\hline
\end{tabular}


Table 3 Forecast of the development of nautical tourism in Serbia [number of nights]

\begin{tabular}{|c|c|c|c|c|c|c|c|}
\hline \multicolumn{4}{|c|}{ Current position } & \multicolumn{4}{|c|}{ Estimation of market potential } \\
\hline \multicolumn{2}{|c|}{ Number } & \multicolumn{2}{|c|}{$\%$} & \multicolumn{2}{|c|}{ Number } & \multicolumn{2}{|c|}{$\%$} \\
\hline \multicolumn{2}{|c|}{26,572} & \multicolumn{2}{|c|}{0.4} & \multicolumn{2}{|c|}{450,000} & \multicolumn{2}{|c|}{3.0} \\
\hline \multicolumn{2}{|c|}{ Domestic } & \multicolumn{2}{|c|}{ Foreign } & \multicolumn{2}{|c|}{ Domestic } & \multicolumn{2}{|c|}{ Foreign } \\
\hline Number & $\%$ & Number & $\%$ & Number & $\%$ & Number & $\%$ \\
\hline 26,572 & 100.0 & 0 & 0.0 & 382,500 & 85.0 & 67,500 & 15.0 \\
\hline
\end{tabular}

Source: The Ministry of Trade and Tourism of Serbia [2006b]

It is evident that the Danube with its banks is a 'unique selling point' of Serbia. In a wider perspective, the Serbian section of the Corridor VII is an actual tourism product launched at the international market (The Government of the Republic of Serbia - Ministry of Trade and Tourism, 2006b).

On the basis of the results obtained in this research, the following programmes can be offered to improve the positioning of Serbia among cruises along the Corridor VII: the Danube; the Balkans; the Serbian culture; the old cities of Novi Sad and Belgrade; the medieval fortresses on the Danube; multiculturality; the Djerdap Gauge and Josip Broz Tito.

In this manner it is possible to create a heterogeneous tourism product that focuses on a high quality of experience and uniqueness of supply compared to other countries-competitors. In addition to international promotion, specific sites/ attractions would provide a direct economic profit from selling tickets, souvenirs and providing various services (a ride on a hackney coach, traditional arts and crafts, food, etc.).

According to the data on the nights spent in Serbia within nautical tourism (Table 3), one may conclude that no international tourists visit the Serbian rivers. This, however, is not the case (Table I). Although participants of cruises along the Corridor VIl spend their nights on traveling ships (these are not treated as the Serbian territory), these participants should be statistically treated as passengers in transit. The fact must be taken into account that participants of cruises spend approximately 72 hours on the Serbian section of the Corridor VII.

\section{Discussion}

Serbia, like other receptive countries, can obtain economic effects in various manners from ships landing in Novi Sad and Belgrade during cruises along the Corridor VIl. First, various subjects can be included in designing tourism supply (promotion, selling) and attracting domestic and, more importantly, foreign investment in receptive areas. For example, there was only one dock for cruisers in 2002 but the number rose to four in 2008 .
Also, during 2008, there was a reconstruction of the dock in Novi Sad, which eased the access of buses to dock for the purpose of accepting passengers from ships.

Tourism in its totality, as well as tourism cruises, contribute to new job openings (Ivkov, Kovačević, Dragin, Djurdjev, Ivanović, 2007), thereby increasing the employment (especially in the season), primarily in ports. With respect to this fact, it is worth noticing that in 2006 a group of painters from Novi Sad exhibited and sold their works or art to cruising tourists at the Novi Sad quay.

The increase in the overall expenditure through tourist traffic (economic effects of the 'invisible export'), part of which are cruises along the Corridor VIl, involves income through various taxes: landing services (tying and tax); forwarding services; provision of stock (water, fuel); collection of waste from ships; sojourn taxes; bus transport, etc. In addition, guided tours of Novi Sad, Belgrade and other sites provides income to receptive travel agencies. Selling tickets for visits to monuments and cultural institutions in Belgrade and Novi Sad (the Museum of the City of Novi Sad, Ethnographic Museum in Belgrade) contributes to increased income of local communities, and similar effects are obtained through individual expenditure during visits to the mentioned areas (purchase of souvenirs, postcards, food, drinks and refreshments).

Multiplied effects of cruises along the Corridor VIl can already be seen in the increase of the total tourist traffic in Serbia, as well as in discovering Serbia as a tourist destination on potential emittive international markets. Further support of cruises on the Corridor VII may contribute to the awareness among tourists that Serbia is an attractive destination with significant natural wealth protected natural areas in the bank region of the Danube (national parks, natural reserves), attractive hydrographic objects (the Danube and other waterways), geomorphological objects (the Djerdap Gauge), and cultural and social values such as multiethnicity, multiculturality and significant cultural heritage (archaeological sites, medieval fortresses, authentic urban and rural environment, etc.). 
The advantages of cruises include: the content of the supply/tour, comfort, and safety. Given these advantages, further development of the competitiveness of cruising tours along the Corridor VIl requires specific measures, such as a more intensive promotional appearance at international markets (fairs, exhibitions, internet presentations), enhanced investment in attractive localities, distribution of domestic products to foreign visitors (souvenirs, food products) on ships or to localities in itineraries, etc.

Disadvantages or delimiting factors for a more successful market valorization of cruises along the Serbian section of the Corridor VII include: underdeveloped infra and suprastructure (traffic signalization, exchange offices, parking lots, restaurants, bars), little time spent at itinerary destinations (the average duration of a stay on a tour of Novi Sad is 3-5 hours), etc.

\section{Conclusion}

The research presented in this paper suggests positive multiple effects that the cruises have upon the economic and tourism development of Serbia, as well as its better international positioning. It can be said that cruises along the Corridor VII bring about multiple effects that include the development of economic activities, design and ranking of a complex tourism supply, as well as a positive image of Serbia at the international market. At the social and economic level, important are the effects related to increased employment in various tourism-related sectors and a favorable climate for attracting domestic and foreign investors. A great significance is given to the effects that lead to the strengthening of regional tourism integrations via the Corridor VII, as well as to connecting cultures of different ethnic communities, the representatives of which are both tourists on cruises and tour providers.

This form of tourism is beginning to occupy a more significant position in Europe. The results can therefore support a stronger promotion of cruises in Serbia as a highly effective segment of international tourist traffic in this country.

Cruises in Serbia procede only along the Corridor VII, that is, along the Danube, a small section of the Sava and in part along the Tisza. Given what has been said so far, it follows that the Danube is the axis of international tourist cruises in Serbia.

The fact is that the waterways other than the Danube, Sava and Tisza are excluded from the cruising tours through Serbia even though these waterways offer a pallette of various complementary contents. The problem does not lie in the lack of adequate infra and suprastructure but in insuf- ficient promotional activity by Serbia. It is necessary to activate attractive localities which are not included in itineraries of Corridor VII cruises although they are situated on the navigation path.

The realization of tours along the Corridor VII requires opening new job positions. However, sometimes new posts are opened indirectly, not only for the purpose of satisfying the needs of cruise companies. Such is the case with the opening of a souvenir market in Novi Sad where souvenirs created by local artists are exhibited to tourists landing from a ship.

We can therefore conclude that cruises along the Corridor VII can contribute to the promotion of the Danube region in Serbia, in particular, the promotion of specific centers and localities, to a greater extent than used to be the case up to now. This means that cruise tourism can function as a strong impetus for reviving those regions in Serbia that during the past two decades have stagnated both socially and economically.

In order for cruises along the Corridor VII to provide prosperity in the forthcoming period, it is necessary that this form of tourism be integrated into plans and programmes of tourism development of the entire Corridor VII and Serbia as a whole. However, without adequate plans for nautical tourism, the reconstruction of the existing and new infrastructure and increase in service quality, it is reasonable to expect a decline in the competitiveness of the Serbia's supply at the international cruise tourism market. In this manner, positive effects of the entire tourism economy will be diminished.

\section{Acknowledgment}

The research that is presented here is part of the project approved by the Ministry of Science of the Republic of Serbia (Demographic Transition in Serbia No. $1460 I 7 d)$ and also a part of the doctoral dissertation defended by Aleksandra Dragin at the University of Novi Sad in 2008.

The research part was accomplished with the help of the following cruise line companies: "Grand Circle Travel“", „Vantage Delux World Travel“, „Croisi Europe”, „Viking River Cruises", "Avalon Waterways", "Phoenix Reisen Gmbh" and other. A great support were ship captains, especially Frank Versluis and Pavol Buzgovič. We express immense gratitude for valuable information to the director of Port authority "Novi Sad", Mr. Boris Oreb, personnel of the Pier „Novi Sad“, Port of Belgrade, „Border police Novi Sad“ (Port of Novi Sad) and personnel of the Pier "Novi Sad 2" (Public Communal Enterprise "Gradsko zelenilo", Novi Sad), especially Vojislav Dragin, Jovan Stanisavljević, Zlatko Grabež and Branimir Lazić. The authors also would like to thank the cruise line 
employees who also participated in the interviews for their valuable time, as well as all other employees of the cruise company, especially Nikola Vuksanović and Prof Gerhard Skoff (president of the Danube Tourist Commission).

\section{References}

Armenski, T., Pejovic, L., Dragin, A. 2009. Building up the destination image - case study of event, city-break and cruising tourism in Serbia. 3rd Advances in tourism marketing conference, University of Bournemouth (United Kingdom), from 6 to II. September, Bournemouth, UK.

Armenski T., Zakić, L., Dragin, A. S. 2009. The Perception of Foreign Tourists on the Image of Serbia. Bulletin of the Serbian Geographical Society 89, I, 53-64.

Braun, B., Xander, J., White, K. 2002. The impact of the cruise industry on a region's economy: a case study of Port Canaveral, Florida. Tourism Economics 8, 28I-288.

Brida, J. G., Aguire, S. Z. 2008. The Impacts of the Cruise Industry on Tourism Destinations. Research Unit on Sustainable Development. University of Milano Bicocca.

Chase, G., Alon, I. 2002. Evaluating the economic impact of cruise tourism: a case study of Barbados. Anatolia: An International Journal of Tourism and Hospitality Research I3, I, 5-I8.

CLIA 2005. Industry predicts cruising will be vacation of choice in 2005, Cruise Line International Association News Releas. Available at www.cruising.org (accessed i9 January 2005).

Dowling, R. K. 2006. Cruise Ship Tourism (Oxfordshire: $\mathrm{CABI}$ ).

Dragin, A. et al. 2006. Nautical tourism as development potential of the Danube countries in south eastern Europe, Danubius Pannonico Mysicus, Space of Challenges, page 28 (Novi Sad: the University of Novi Sad, the Faculty of Science).

Dragin, A.S., Dragin, V., Plavša, J., Ivkov, A., Djurdjev, B.S. 2007. Cruise Ship Tourism on the Danube in Vojvodina Province as a Segment of Global Tourism. Geographica Pannonica II, 59-64.

Dragin, A.S., Djurdjev, B.S., Armenski, T. 2008. Do the cruisings along the Corridor VII belong to tourist movements of elderly people? Bulletin of the Serbian Geographical Society 88, 4, 2938. (in Serbian)

Dragin, A. 2008. International Cruising along Corridor VII and nautical tourism in Serbia (doctoral dissertation) (Novi Sad: University of Novi Sad, Faculty of Science).

Dragin, A. 20Io. International Tourist Cruises along the Corridor VII and Novi Sad. Univer- sity of Novi Sad, Faculty of Science, 32I pp. (in Serbian)

Dragin, A., Bubalo-Živkovic, M., Ivanović, Lj. 2009. The Romanians on international cruises along the Corridor VII: The structure of the crew on tourist boats. Geographica Timisiensis I-2, 35-44.

Duman, T., Mattila, A. S. 2005. The role of affective factors on perceived cruise vacation value. Tourism Management 26, 3II-323.

Dwyer, L., Forsyth, P. I996. Economic impacts of cruise tourism in Australia. Journal of Tourism Studies 7, 36-43.

Dwyer, L., Forsyth, P. I998. Economic significance of cruise tourism. Annals of Tourism Research 25, 2, 393-4I5.

Field, D. R., Clark, R. N., Koth, B. A 1985. Cruise ship travel in Alaska: a profile of passengers. Journal of Travel Research 24, I, 2-8.

Foster G. M. I986. South seas cruise a case study of a short-lived society. Annals of Tourism Research $\mathrm{I}_{3}, 2,2 \mathrm{I} 5-238$.

Gabe, T. M., Lynch, C. P., McConnon, J. C. 2006. Likelihood of cruise ship passengers return to a visited port: the case of Bar Harbor, Maine. Journal of Travel Research 44, 28I-287.

Gibson, P. 2004. Life and learning in further education: constructing the circumstantial curriculum. Journal of Further and Higher Education $28,3,333-345$.

Gibson, P. 2006. Cruise Operations Management (Burlington: Butterworth Heinemann).

Gibson, P. 2008. Cruising in the $2 \mathrm{I}^{\text {st }}$ century: Who works while others play? International Journal of Hospitality Management 27, 42-52.

Go, M.F. \& Pine, R. I995. Globalization Strategy in the Hotel Industry (London: Routledge).

The Government of the Republic of Serbia 2005. Strategy of Tourism Development in Serbia until 2015 (Belgrade: Government of Republic of Serbia).

The Goverment of Republic of Serbia - Ministry of trade and tourism 2006a. Strategy of Tourism Development in Serbia (Drugi izveštaj, Strateški marketing plan) (Belgrade: Government of Republic of Serbia).

The Goverment of Republic of Serbia - Ministry of trade and tourism 20o6b. Strategy of Tourism Development in Serbia (Drugi izveštaj, Plan konkurentnosti) (Belgrade: Government of Republic of Serbia).

Grand Circle Travel 2005. Small Ship Travel 2006 (Boston: GCT).

Guyer, C., Pollard, J. I997. Cruise visitor impressions of the environment of the Shannon-Erne waterways system. Journal of Environment Management 5I, I99-2I5.

Hall, J. A., Braithwaite, R. I990. Caribbean cruise tourism. Tourism Management II, 4, 339-347. 
Henthorne, T. L. 2000. An analysis of expenditures by cruise ship passengers in Jamaica. Journal of Travel Research 38, 246-250.

Hobson, J. P. I993. Analysis of the US cruise line industry. Tourism Management I4, 453-462.

Hung, K., Petrick, J. F. 20Io. Developing a measurement scale for constraints to cruising. Annal of Tourism Research 37, I, 206-228.

Ivkov, A., Kovačević, T., Dragin, A., Djurdjev, B., Ivanović, Lj. 2007. Influence of tourism on the employment in Vojvodina. Geographica Pannonica II, 54-58.

Jaakson, R. 2004. Beyond the tourist bubble? Cruise ship passengers in port. Annals of Tourism Research 3I, I, 44-60.

Jovicic, D. 2000. Tourism and Environment in the Context of Sustainable Development (Belgrade: Andrejevic). (in Serbian)

Li, X. 2006. Examining the antecedents and structure of customer loyalty in a tourism context. Unpublished dissertation. Texas A\&M University, College Station.

Li, X., Petrick, J. F. 2008. Examining the antecedents of brand loyalty from an investment model perspective. Journal of Travel Research 47, 25-34.

Mancini, M., 200o. Cruising a Guide to the Cruise Line Industry. Delmar, Albany, NY.

Marti, B. I992. Passenger perceptions of cruise itineraries. Marine Policy 24, 4, 360-370.

Marti, B. E. 2004. Trends in world and extendedlength cruising (1985-2002). Marine Policy 28, I99-2II.

Mescon, T., Vosikis, G. I985. Economic Impact of Tourism at the Port of Miami. Annals of Tourism Research $\mathrm{I} 2$, 515-528.

Peisley, T. 1992. The world cruise ship industry in the I990's. Special Report No. 2104. London: Economist Intelligence Unit.

Peisley, T. 2006. The future of cruising - boom or bust, Seatrade Research Report (Colchester: Seatrade).

Petrick, J. F. 2003. Measuring cruise passengers' perceived value. Tourism Analysis 7, 3/4), 25I-258.

Petrick, J. F. 2004. The role of quality, value, and satisfaction in predicting cruise passengers' behavioral intentions. Journal of Travel Research 42, 397-407.
Petrick, J. F., Sirakaya, E. 2004. Segmenting cruisers by loyalty. Annals of Tourism Research 3I, 2, I72-I73.

Petrick, J. F. 2005. Segmenting cruise passengers with price sensitivity. Tourism Management 26, 753-762.

Phoenix Reisen Gmbh 2006. Fluss und Küsten 2008 (Bonn: Phoenix Reisen Gmbh).

Qu, H., Wong, E., Ping, E. W. Y. I999. A service performance model of Hong Kong cruise travelers' motivation factors and satisfaction. Tourism Management 20, 237-244.

The Statistical Office of the Republic of Serbia 2006. Municipalities in Serbia in 2005 (Belgrade: The Statistical Office of the Republic of Serbia).

The Statistical Office of the Republic of Serbia 2008. Municipalities in Serbia in 2007 (Belgrade: The Statistical Office of the Republic of Serbia).

Sofield, H.B.T. 2006. Border tourism and border communities: an overview. Tourism Geographies 8, 2, IO2-I2I.

Teye, V. B., Leclerc, D. I998. Product and service delivery satisfaction among North America Cruise passengers. Tourism Management I9, 2, 153-160.

Vantage 2007. Deluxe World Travel Vantage 2007/2008 - First 2008 Announcement! European River Cruises, Small Ships, Escorted Land, Ocean Cruises (Boston: Vantage).

Ward, D. 2005. Complete Guide to Cruising (London: Berlitz Publishing).

Williams, A., M \& Hall, M., C. 200o. Tourism and migration: new relationships between production and consumption. Tourism Geographies 2, I, 5-27.

Wood, R. E. 20oo. Caribbean cruise tourism: globalization at sea. Annals of Tourism Research 27, 2, 345-370.

WTO 2003. Worldwide Cruise Ship Activity (Madrid: WTO).

Data of the 'Novi Sad' Port.

Data of the 'Beograd' Port.

Data of the Border Police Station of Donji Milanovac http://cruise.croisieurope.com http://www.danube-river.org/site/content

http://www.srbija.travel/turisticki-promet-u-republici-srbiji-u-2009-godini/ 